\title{
Erratum to: Effect of different storage temperature on chemical composition of onion (Allium cepa $\mathrm{L}$.) and its enzymes
}

\author{
Kavita Sharma $^{1}$ Y Yong Rok Lee ${ }^{1}$
}

Published online: 1 December 2015

(C) Association of Food Scientists \& Technologists (India) 2015

Erratum to: J Food Sci Technol

DOI 10.1007/s13197-015-2076-9

The published online version contains mistake on the affiliation section. The correct version is shown below.

The online version of the original article can be found at http://dx.doi.org/ $10.1007 / \mathrm{s} 13197-015-2076-9$

$\triangle$ Yong Rok Lee yrlee@yu.ac.kr

School of Chemical Engineering, Yeungnam University,

Gyeongsan 712-749, Republic of Korea 